\title{
THE FORMALISATION OF ISLAMIC ATTIRE IN PADANG, WEST SUMATRA ${ }^{1}$
}

\author{
Deny Hamdani \\ UIN Syarif Hidayatullah, Jakarta
}

\begin{abstract}
This study examines the formalisation of Islamic attire among Minangkabau people - particularly among school students in Padang, West Sumatra - in the spirit of the regional autonomy of post-Soeharto Indonesia. It focuses on the conceptualisation and enforcement of the Mayor's policy concerning Islamic attire for students in the Mayoral Decree (No. 451.422/2005) in line with the rampant Shari ah-influenced by-laws throughout West Sumatra. I argue that the formalisation of Islamic attire has been unproductive in terms of promoting Islamic precepts because veiling is an ever-contested concept within the complex Muslim social structure. The imposition of this 'contested concept' has led to veiling becoming an 'imposed choice' that has assumed a formal meaning as proper religious attire for the wearer. Instead of enhancing religious awareness, the imposition of Islamic attire on students in public schools has failed to encourage a personal awareness of religious and cultural identity in them.
\end{abstract}

Keywords: Regulation of Islamic attire, Mayor's policy, Shari h-influenced by-laws, Perda.

\section{Introduction}

The emergence of Sharith-influenced by-laws has opened a new chapter in the "drama of Indonesian Islam" after Muslim aspirations were marginalized for several decades by the New Order regime. Although pro-Muslim regulations were issued by the ruling regime in

\footnotetext{
1 This article is part of my dissertation's chapters entitled “The Quest for Indonesian Islam: Contestation and Consensus Concerning Veiling" submitted to The Australian National University, April 2007.
} 
the early 1990s, the impetus of Islamists to infuse the public domain with Islamic precepts has not abated. Political will to Islamize various aspects of life has become a seed growing among them to be replanted continuously into a formal entity. This inclination is obvious in the concept of Islamic attire (busana Muslim) which has shifted dramatically from the New Order period to the reform era (era reformasi). No one predicted that Islamic veiling would be imposed on female Muslims on behalf of local policy, according to which such Muslim uniforms had been previously barred by government in the name of regulation. The idea of obliging Muslims to wear Islamic attire in public life -which is accommodated in Sharin-influenced by-laws- has clearly demonstrated the dramatic changes in the Indonesian social and political constellation.

The growing trend in many regions to formalise Islamic veiling has become the nexus of what Boland identifies as a "partial realisation of Islamic law" or "positivizing Sharith in different social settings. ${ }^{2}$ Instead of campaigning for an Islamic state, certain Indonesian Muslims groups have recently instituted elements of Islamic law in accordance with the Jakarta Charter, which had been proposed in 1945. In this charter, the aspiration of Muslims to undertake their religious obligations was constitutionally guaranteed. The current Islamic movement has utilised opportunities presented by regional autonomy since 2001, and depends on the situation and the 'tactics' to be followed. In terms of the promotion of Islamic veiling, its formalisation in various regional acts (Peraturan Daerah, or Perda) has resulted in a significant enhancement of its status from a living practice among Muslims to part of a legalised framework. In Kuntowijoyo's view, this social and political transformation has inevitably ignored the old approach, which was based on individual awareness, and which became the core of 'the cultural strategy' employed by the Islamic movement in Indonesia during the New Order. ${ }^{3}$

This paper explores how some Minangkabau people in Padang, West Sumatra have negotiated the imposition of Islamic attire in the

\footnotetext{
2 See B. J. Boland, The struggle of Islam in Modern Indonesia (Leiden: The Hague-Martinus Nijhoff, 1971), p. 164; J. R. Bowen, Islam, Law, and Equality in Indonesia: An Anthropology of Public Reasoning (Cambridge, UK: New York, Cambridge University Press, 2003).

${ }^{3}$ Kuntowijoyo, Muslim tanpa Masjid: Esai-esai Agama, Budaya, dan Politik dalam Bingkai Strukturalisme Transendental (Bandung: Mizan, 2001), p. 120.
} 
name of regulating religious tenets with the claim of local identity. I argue that the formalisation of Islamic attire has been unproductive in promoting Islamic precepts because veiling is an idea that is incessantly contested within the complex Muslim social structure. The imposition of this 'contested concept' has led to veiling becoming an 'imposed choice' that has assumed a formal meaning as proper religious attire for the wearer. Instead of enhancing religious awareness, the imposition of Islamic attire on students in public schools has failed to encourage a personal awareness of religious and cultural identity in them. The enforcement of the laws requiring Islamic attire has been ambiguous and half-hearted because of the uncertain conceptualization of Islamic veiling. This research discusses the problematic conceptualisation and enforcement of Islamic attire in Padang, where Islam and adat (local custom) are negotiated to express a collective identity in the changing conditions of everyday Minangkabau life.

\section{The Regulation of Islamic Attire}

Following the collapse of the New Order regime, the social and political constellation in Indonesia changed from a centralised to a decentralised system. ${ }^{4}$ Decentralisation took the form of a massive redistribution of extensive powers and authority to regional administrations that were now expected to manage their own internal affairs according to local aspirations rather than central policy. Six administrative areas were excluded from this arrangement: foreign affairs, defence, the judiciary, the monetary and fiscal departments, and religion. ${ }^{5}$ Local elites have used this opportunity to strengthen local identity on the one hand, and to revive old traditions on the other. The aspirations of the Minangkabau people to maintain their customary practices are reflected in a local saying: kembali ke nagari ('return to the traditional Minangkabau village') and kembali ke surau ('return to the local house of prayer'). ${ }^{6}$ The realisation of these local aspirations seems

\footnotetext{
${ }^{4}$ Decentralisation was realised by the issuance of Law No. 22/1999 regarding Regional Administration, and Law No. 25/1999 establishing a fiscal balance between the Centre and the Regions.

5 See Regional Administration Law No. 32/2004, Article 10, Clause 3.

${ }^{6}$ This is embodied in a regional act: Perda No. 9/2000 regarding the guidelines for village administration (Ketentuan Pokok Pemerintahan Nagari). Based on this regulation, the lowest administration unit - the nagari or village - is considered very effective in preserving the religious teachings and cultural identities of the Minangkabau people (Perda Sumbar, 2000: 1).
} 
to have had a significant impact, not only on the development of traditional institutions, but also on the complex relationship between Islam and adat (local custom) in the matrilineal Minangkabau society. Since the inception of regional autonomy, Islamic attire has been considered one of the crucial aspects-where veiling is the central issue-of dress code, religious practice and local identity; it is therefore enjoined on Muslims by certain kinds of regulations.

The enforcement of the wearing of Islamic attire has been inscribed in the articles of various regulations in West Sumatra. ${ }^{7}$ Kabupaten Solok (Perda No. 6/2002), Kota Sawahlunto (Perda No.2/2003), Kabupaten Lima Puluh Kota (Perda No. 5/2003), Kabupaten Pasaman (Perda No. 22/2003), Kabupaten Pesisir Selatan (Perda No 4/2005) and Kabupaten Agam (Perda No.6/2005) have all formalised Islamic attire in regional acts (Perda). Some regional bureaucracies prefer to issue a 'call to action' (surat himbanan) rather than a Perda, although the former, unlike a Perda, is not binding. ${ }^{8}$ Local

7 Beyond West Sumatra, other regions have also institutionalised Islamic veiling. For
example, West Java issued Letter No. 551/2717/ASSDA.I in September 2001
concerning the Civil Service Movement initiated by the Bupati of Cianjur to implement
good behaviour (Gerakan Aparatur Berakblakul Karimah dan Masyarakat Marbamab);
letters from the Bupati of Cianjur (No. 025/3643/Org and No. 061.2/2896/Org),
about working hours and work uniforms for Muslims (Jam Kerja dan Anjuran Pemakaian
Seragam Kerja [Muslim/Muslimah] pada Hari-hari Kerja); and a letter from the Bupati of
Indramayu about the obligation to wear Islamic attire and undertake training in the
Qur'an (Wajib Busana Muslimah dan Pandai Baca Al Qur'an). In South Sulawesi the
following regional acts (Perda) were issued: Regional Act No. 04/2003 in Kabupaten
Bulukumba about wearing Islamic attire (Berpakaian Muslim dan Muslimab); Regional
Act No. 6/2005 in Kabupaten Enrekang about Islamic attire (Busana Muslim); and
Regional Act No. 15,16,17/2005 in Kabupaten Maros about people's inability to read
the Qur'an, Islamic attire and the management of alms-giving (zakat) (Buta Aksara Al
Qur'an, Busana Muslim dan Pengelolaan Zakat).

8 Article 7 of the Law regarding Legal Enactments (Pembentukan Peraturan Perundangundangan - No. 10/2004 - stipulates five levels in the legal hierarchy: the Constitution (Undang-undang Dasar); Laws (Undang-undang) or Governmental Regulations enacted to substitute for the Law (Peraturan Pemerintah Pengganti Undang-undang, Perpu); Governmental Regulations (PP, Peraturan Pemerintah); and Regional Acts (Peraturan Daerah). Letters from regional leaders (kepala daerah) are not included in this list. Nevertheless, in terms of administrative law, as the executive agent of local government, a regional leader has an inherent authority called Freies Ermessen, under which he/she can make regulations about matters not yet covered by law, or to implement an existing rule. This authority is also called 'discretionary power'. A government is not allowed to act beyond its authority (detournement de pouvoir), however, or against the law (onrechtmatige overheidsdaad). See S.F. Marbun \& Mahfud M.D., Pokok- 
veiling policies that rely on bureaucratic authority can be found in Kabupaten Padang Panjang (No. 800/2993/BKD-PP/2003), Kabupaten Tanah Datar (No. 430/228/Kesra-2004) and Kota Padang (No. 451.422/Binsos-iii/2005). ${ }^{9}$

Unlike other 'calls to action', the local policy in Padang has attracted public attention for several reasons. First, the media pay more attention to Padang ${ }^{10}$, as a provincial capital, than to other regions. In several Jakarta-based journals, ${ }^{11}$ the Padang Mayor's policy of formalising Islamic attire by Decree (No. 451.422/2005) has sparked controversy on the national stage, despite policies regarding Islamic attire being widespread in West Sumatra. The reason is that the Mayor's policy is problematic and ambiguous. It is ambiguous because it includes a recommendation that compliance be voluntary, but its articles clearly use the words 'oblige' (mewajibkan) and 'obliged' (diwajibkan) as if Islamic dress were legally mandatory for women. This differs from a local policy in Tasikmalaya, West Java, where the 'call to action' (surat edaran) urging women to wear Islamic attire uses the word dianjurkan ('encouraged' or 'recommended') in accordance with the

pokok. Hukum Administrasi Negara (Yogyakarta: Liberty, 1987), pp. 46-7. Such rules (those set out in official letters) cannot be binding regulations for the people.

9 The Kabupaten (regency) and kota (city) are local administrations which have similar levels of authority under the provincial government. While the kabupaten tends to include villages characterised by farming and agricultural affairs, kota are usually urban settlements which rely on economic support from non-agricultural sources.

10 Padang is located about halfway down the West Sumatran coast. This city extends from Padang Pariaman in the north to Pesisir Selatan in the south and stretches from Solok in the east to the Indian Ocean in the west. Padang's territory covers $695 \mathrm{~km}^{2}$ of the total area of West Sumatra, which is $42,297.021 \mathrm{~km}^{2}$. Annual population growth averaged $1.27 \%$ between 1990 and 2000. The current population is 756,014, that is, sixteen percent of the total population of the province, which is 4.46 million (BPS Sumbar, 2003:41). Padang's weather is tropical and wet. Temperatures range between $28.5^{\circ} \mathrm{C}$ and $31.5^{\circ} \mathrm{C}$ during the day, and $24^{\circ} \mathrm{C}$ and $25.5^{\circ} \mathrm{C}$ at night. See M. Safwan \& Proyek Inventarisasi dan Dokumentasi Sejarah Nasional (Indonesia), Sejarah Kota Padang (Jakarta: Departemen Pendidikan dan Kebudayaan, Direktorat Sejarah dan Nilai Tradisional, Proyek Inventarisasi dan Dokumentasi Sejarah Nasional, 1987), p. 62.

11 A private TV channel broadcasted a talk-show program presenting the Mayor of Padang, Fauzi Bahar, and a panel of local politicians. In addition, Tempo magazine questioned the policy of the Mayor in an article entitled "Kerudung Bersendi Pak Wali and Ihwal Kerudung Wajib di Padang” (May 22, 2005). 
nuanced approach of the moral movement. ${ }^{12}$ The policy of the Padang administration is problematic because it has challenged the complex social structure of Padang: the Minangkabau people are not the only social group in the urban area, where many non-Muslim people also live.

Instead of enforcing Islamic attire by a specific regulation, the Mayor's policy has been implemented through programs for students offered at various educational levels. These programs include wirid remaja ('teenage gatherings for ritual activities'), an intensive program of didikan subub (a dawn religious class), an anti-togel campaign (antiillegal gambling), ${ }^{13}$ an anti-drug (narkoba) movement, ${ }^{14}$ and encouraging Islamic attire (busana muslim). The wirid remaja are aimed at junior and senior high-school students (SLTP and SLTA), ${ }^{15}$ while the didikan subuh is aimed at elementary schools (Sekolah Dasar, SD). The other two programs target all levels of education, encompassing elementary school (SD/MI), ${ }^{16}$ junior high-school (SLTP/MTS) ${ }^{17}$ and senior highschool (SLTA/SMK/MA) ${ }^{18}$ students. While the anti-togel (illegal

12 This 'call to action' is inscribed in letter No. 451/SE/04/Sos/2001 concerning efforts to enhance religiosity and piety (Upaya Peningkatan Kualitas Keimanan dan Ketaqwaan). This policy is part of a campaign to improve people's skill in reading the Qur'aæ, it involves attendance at religious school after formal school hours.

13 Togel stands for toto gelap, literally a 'dark,' or illegal lottery.

14 Narkoba stands for narkotika dan obat-obat terlarang ('narcotics and illegal drugs')

15 SLTP stands for Sekolah Lanjutan Tingkat Pertama, while SLTA stands for Sekolah Lanjutan Tingkat Atas.

$16 \mathrm{SD}$ and MI are at the same level of elementary education. SDs tend to be secular, while MIs are denominational institutions belonging to the Islamic community which are usually managed by private organisations. Although MI stands for Madrasah Ibtidaiyah (Arabic), which means 'elementary school', the curriculum at MI contains more Islamic subjects than that used at SD.

17 SLTP and MTS both refer to junior high-schools. While the SLTP is a secular institution, MTS, which stands for Madrasab Tsanawiyah (Arabic), is an Islamic institution which offers more Islamic subjects than an SLTP.

18 SLTA, SMK, and MA are acronyms referring to the same level of senior highschool, but each institution has special characteristics. The SLTA is usually called SMA, Sekolah Menengah Atas, or SMU, Sekolah Menengah Umum; these institutions are general senior high-schools offering no specialisation. In contrast, the SMK, which stands for Sekolah Menengah Kejuruan (Vocational School), offers specialisations, for example engineering, or tourism. While all three types of school are secular, MA, which stands for Madrasah Aliyah (Arabic), or senior high-school, provides an Islamicoriented education. Although the MA are not professional religious schools for clerics, 
gambling) and anti-drugs (narkoba) movements do not consider religious affiliation, the obligation to wear Islamic attire (busana muslim) is directed only at Muslims. Even so, the final regulation states that non-Muslim students should 'adjust' (menyesuaikan dir) to Muslim dress by wearing baju kurung ${ }^{19}$ for girls and long pants for boys. ${ }^{20}$

The distinctions made between the school uniforms worn by Muslim and non-Muslim students and favored by the Mayor's policy have not been backed up by specific regulations at particular schools. I found that senior high-school uniform regulations still refer to the existing national regulation for school uniforms (SK 100/1991), ${ }^{21}$ which already accommodates both Islamic and 'secular attire'. The standard Islamic costume for girls as described in the regulation is a headscarf, a long-sleeved shirt and a long skirt. ${ }^{22}$ Since the Mayor's policy does not specify a new standard for uniforms, Muslim students continue to follow the existing national regulation, while non-Muslim students modify the national model, leaving out the headscarf. The wearing of headscarves by Muslims has become common in many educational institutions, although veiling and the baju kurung are only compulsory on Fridays. ${ }^{23}$ In order to display local identity, non-Muslim students are also obliged to wear long-sleeved shirts and long skirts on Fridays, but without the headscarf. Nevertheless, the regulations on

these institutions offer many more Islamic subjects than do the other two kinds of high-school.

19 Baju kurung refers to the traditional Minangkabau long-sleeved, loosely fitting women's tunic that reaches to slightly above or below the knees. See L. A. Whalley, "Virtuous Women, Productive Citizens: Negotiating Tradition, Islam, and Modernity in Minangkabau, Indonesia," Unpublished PhD thesis, University of Illinois, UrbanaChampaign (1993), p. 309.

20 As inscribed in the letter of instruction (surat instruksi) No. 451.422/Binsos-iii/2005.

21 The complete reference to the regulation is SK No. $100 / \mathrm{C} / \mathrm{Kep} / \mathrm{D} / 1991$. This regulates school uniforms, and complements SK No. 052/C/Kep/D 82, which concerns the guidelines for school uniforms from kindergarten to senior high-school. Both regulations were produced by the Ministry of Education and Culture.

22 See SK 100/1991.

23 The rules of SMAN 2 Padang stipulate that female students should wear the jilbab and the baju kurung every Friday. The regulation has been in force since 2003. 
veiling and baju kurung are only set out in the guidelines for school policy, and there is no detailed explanation about the uniform. ${ }^{24}$

Since regulations about Islamic attire remain unclear, the efficacy of a given policy relies quite heavily on the charisma of individual bureaucrats. Because the Mayor's policy had no constitutional or binding power over the people, ${ }^{25}$ the Mayor employed 'a set of techniques and devices to transcend the use of rationality in his political action[s]': Bensman identified this as 'modern charisma'. ${ }^{26}$ When the Mayor launched his policy, he used the classical technique of persuading people through plausible arguments. He speculated that the imposition of Islamic attire would prevent sexual harassment. Instead of investigating the complex origins of criminal conduct, he concluded that sexual harassment occurs because the aurat (part of the body considered as private according to Islamic Sharith) is flaunted: this invites harassment. ${ }^{27}$ In public, the Mayor stated that he was committed to improving the personal behaviour and morality of students as prescribed by Islamic teachings. ${ }^{28}$ To further his purpose, the Mayor summoned the school principals of Padang to a meeting to discuss his policy of making Islamic attire compulsory in schools. ${ }^{29}$

Unlike the veiling conflicts (kasus jilbab) that occurred in Java during the New Order regime, ${ }^{30}$ wearing the Islamic head-covering at

${ }^{24}$ In a guideline included in the school rules of SMA 2 Padang, it is written that female students should wear baju kurung and jilbab (the headscarf) on Fridays, while male students should wear baju koko. This item appears in the section on clothing, Chapter 4, Clause 27.

25 According to the new legal hierarchy, Perda is the 'lowest' law that binds the people. The Mayor's policy (SK Walikota) is not even a Perda law, however.

${ }^{26}$ J. Bensman, \&. M. Givant, "Charisma and Modernity: The use and abuse of a concept," in R. M. Glassman, \& WH. Swatos, Jr (eds.), Charisma, History and Social Structure (New York: Greenwood, 1986), p. 52.

${ }^{27}$ Haluan 02/11/2005. Haluan is the local Padang newspaper.

${ }^{28}$ D. Munir \& Padang (Indonesia) Dinas Infokom, 1 tabun Walikota \& Wakil Walikota Padang: Drs. H. Fauzৃi Bahar, M.Si \& Drs. H. Yusman Kasim: 18 Februari 2004-17 Februari 2005 (Padang: Dinas Infokom Kota Padang, 2005), p. 131

${ }^{29} \mathrm{My}$ informant told me that there was a meeting of all the school principals in Padang and the Mayor, where they discussed the imposition of Islamic attire.

${ }^{30}$ Conflicts over veiling occurred in certain regions of Java. They arose in response to the restrictions imposed by the state vis-à-vis the growing desire to wear the jilbab (headscarf) among female students at public schools. See A. Alatas \& F. Desliyanti, 
public school seems to have been unproblematic in West Sumatra; it had became a daily practice for many students before the Mayor issued his policy. School administrations played a significant role in supporting or rejecting this practice. In Padang, teachers and principals generally welcomed the enforcement of Islamic attire after the announcement of the Mayor's local policy. At SMAN 2 Padang, for example, the new approach to Islamic attire was announced at the distribution of final reports to students' parents at the end of the semester in 2000. The school administration distributed uniform guidelines for the following semester which were in line with the Mayor's new policy. The Mayor's programme was also endorsed by the school administration at SMAN 3 Padang, which organised the students to make a declaration supporting the Mayor's policy at the Islamic New Year celebrations (Hijriab). In addition, the school staged a competition for Islamic attire to which the Mayor was invited. In recognition of this effort, the Mayor announced that SMAN 3 Padang was the 'laboratory' for Islamic attire in Padang. ${ }^{31}$ Another instance of support on the part of school administrations at the junior high-school level can be found at SMPN 20 Padang. At this school, serious attention is paid to Islamic attire, and it is part of the school guidelines. The policy, inscribed in big letters on the wall of the school, states that "those who wear tight shirts or short skirts [hemmed above the knees] will have their grades reduced by fifty points (-50) from a maximum of 100 points."

In practice, this point-based reduction of mechanism tends to be inapplicable. Several students that I interviewed admit that they have never tried to wear tight shirts or short skirts in the class room. As Claudia, a third grade student, admits, she doesn't have the courage to wear something different from other students. It would be embarrassing, she said. Instead of being the object of public attention, she prefers to adapt to other students. Therefore, her points have never been reduced because of her uniform. In other words, teachers and school management have never applied the mechanism, due to the

Revolusi Jilbab: Kasus Pelarangan Jilbab di SMA Negeri se-Jabotabek, $1982-1991$ (Jakarta: AlI'tishom Cahaya Umat, 2001).

31 Haluan $03 / 21 / 2005$. 
absence of infringement by those who challenge the inscribed regulation. ${ }^{32}$

Initially, students in Grade One (kelas satu) were targeted because their uniform package included a headscarf, which is more costly than both the unveiled and enveloping modes of dress. At that time, wearing the scarf was optional for Year Two and Three, although teachers 'encouraged' students to wear it. After the Mayor's policy was issued in 2005, however, all students were obliged to wear Islamic attire. At elementary school, teachers tell pupils that wearing Islamic attire is compulsory, and they pass this message on to their parents. At SD Alang Lawas Padang, the six-to-twelve year-old students wear Islamic attire; this consists of long pants for boys and the headscarf for girls.

Since the enforcement of Islamic attire in the public domain was already widespread throughout West Sumatra, the local policy of the Padang educational administration seemingly reinforced and strengthened the aspirations of Minangkabau people to express the unity of Islam and adat (local custom) as their collective identity. As in other parts of West Sumatra, the examples of 'billboard politics' in certain parts of Padang show how Minangkabau people campaign to realise their aspirations. At a bus stop on a main road in Padang, I saw a slogan that read: "Cover your aurat (nakedness) so that God may bless you" (Tutuplah auratmu semoga Allah meridhaimu). ${ }^{33}$ Although it does not mention the source of the message it conveys, this sign embodies Minangkabau aspirations.

These aspirations are also expressed on another billboard set up at the eastern corner of the central square in Padang:

I congratulate the students of Padang junior and senior highschools, and admire their statements regarding [the following]: the eradication of togel (illegal gambling) and the fight against drugs (narkoba); the intensive programs of didikan subub (dawn religious classes) and wirid remaja (teenage

\footnotetext{
${ }^{32}$ However, based on the current monitoring of this school, the inscribed regulation is no longer existed. It has been removed by the school management. One of teachers, Nurliana, admitted that the policy was not applicable. She speculated that it might not be effective to impose the uniform standard by reducing the point. That is why, she agreed to remove the inscribed policy because it is useless (This observation and interview took place in August 2008).

33 Most billboards-including this one-are installed by the Regional Administration (PEMDA).
} 
groups for ritual activities) and the wearing of Islamic attire (busana Muslim)... ${ }^{34}$

\section{Islamic Attire for Students}

Shifts in political power have played a decisive role in changing educational regulations and the style of school uniform accepted in public schools. This is exemplified by the adjustment made to SK 052/1982 35 -the previous national regulation regarding school uniforms-by adding a supplement known as SK 100/199136-reflected the changing attitude and policy of the central government. Both regulations were issued by Dirjen Dikdasmen (the division of the Ministry of National Education which is responsible for elementary and secondary education). The new regulation accepted the Islamic veil as an alternative uniform for female students. In a similar way, the Padang Mayor's policy (No. 451.422/Binsos-iii/2005) was an attempt to exert his power at the local level by standardising the school uniform in terms of Islamic veiling practices.

Instead of imposing Islamic attire on all the people in Padang, the Mayor focused on people working or studying in government settings. He began with his policy on school uniforms, targeting students at all levels from elementary to senior high-school (SD to SMA), who numbered 156,627 young people in 2004. ${ }^{37}$ This means that the policy targeted $19 \%$ of the total population of Padang $(756,014$ people, $96 \%$

\footnotetext{
34 The billboard's message came from Din Syamsudin, Chairperson of the Indonesian Ulama Council (MUI). It remained in place from February 2005 to February 2006.

35 This regulation stipulated the requirements for all school uniforms, from kindergarten (TK) through elementary school (SD), junior high-school (SMP) and senior high-school (SMA), not only in public schools, but also in private schools. This regulation accommodated a form of 'headgear' for female students that resembles a cap or destar/blankon, as a special uniform option (pakaian khas).

36 This regulation constitutes a supplement (penyempurnaan) to the SK052/1982 regulation, that accepted the idea of the veil (kerudung) as an element of female costume in public schools. For certain Muslims, this regulation was a more legitimate government response to the widespread aspiration to wear the Islamic veil at public school.

37 Official data from the Padang Administration in 2004 indicate that there were 96,426 students enrolled in 354 state-owned elementary schools and 60 private ones. This number is much higher than the total junior high-school enrolments, which were 35,492 students studying at 35 public and 39 private schools. Meanwhile, senior highschool enrolment reached 24,709 students in 14 public and 31 private institutions. See Padang Dalam Angka 2004, 73.
} 
of whom were registered as Muslim). The Mayor also intended to recommend that civil servants in the local administration-particularly female staff-wear Islamic attire, ${ }^{38}$ although this intention has not yet been realised. Nevertheless, the institutionalisation of Islamic attire in the bureaucracy has not been followed by a Regional Act (Perda) which might assume coercive power in terms of the constitutional and legal hierarchy.

One important difference between the new local Padang regulation about school uniforms and the existing national regulation is that the latter provides acceptable alternatives as part of the school uniform. The Mayor's policy recommends one single school uniform for all students, that is, Islamic attire, which prescribes the baju kurung and headscarf for girls. Non-Muslim students are thus pressured to wear this costume in order to comply with the clause relating to 'adjusting' (Article 10). This clause recommends that non-Muslim students adjust their style of dress to conform to Muslim standards. In contrast, the existing national regulation provides details of two choices of uniform for girls, the ordinary and 'special' (seragam sekolah khas) versions. The former requires a short-sleeved blouse and a short skirt falling to below the knee, while the latter consists of a long-sleeved blouse, a long skirt and a headscarf. Students may choose which of the two alternative styles of uniform to wear at school in accordance with their own preferences and beliefs. The Mayor's policy omitted the unveiled alternative, however. In other words, the policy of the Padang Administration stipulates one standardised school uniform, while the existing national regulation is open to a choice of uniforms as long as they conform to the general specifications (Chapter I, Article 1, Clause E).

Since the implementation of the policy, all Padang students from elementary to senior high-school have changed their uniform to Islamic costume. This consists of the baju kurung and headscarf for girls and long pants for boys.

During my fieldwork, I found that both male and female students at various education levels 'obeyed' the directive to wear Islamic attire. The policy is not applied in non-Muslim denominational institutions, although the bureaucracy recommends that girls wear the baju kurung. At SMAN 2 Padang, rumors that Islamic attire would be enforced

${ }^{38}$ Haluan 02/11/2005. 
were widespread several months before the Mayor issued his policy. As a result of these rumors, the proportion of students wearing Islamic attire rose from $20 \%$ to $100 \%$, including a few non-Muslim students. Similarly, at SMAN 3 Padang, Islamic attire is worn by all students. As this style of dress for girls was welcomed by both the school administration and the parents of students, the school claims to have been the first institution to implement the new policy on Islamic attire. ${ }^{39}$ At SMPN 2 Padang and SD Alang Lawas the combination of baju kurung and headscarf for girls and long pants for boys is also the common uniform.

Although the shift to Muslim attire occurs only once, the expense is very high, particularly for the female uniform. According to a female senior high-school student in Padang, the new uniform is more expensive because of the extra cloth required for the longer clothes and the additional cost of the headscarves. In addition, up to three versions of the school uniform may be mandatory: a daily (harian), scout (pramuka), and traditional (pakaian adat) uniform, each with its own complementary headscarf. 40 As her father's monthly income was only one million rupiah, replacing her school uniform cost more than sixty percent of the household income. Similar complaints were made by parents, particularly those with children in grade three (kelas tiga). Not only was making the change in uniform costly; the new uniform would only be worn for a short time, because the remaining period of study at the lower elementary level was less than one year. This means that parents would have to replace the old uniform with the new one, which would be discarded not long afterwards.

Female students reacted to the imposition of Islamic attire in a range of different ways. At SMAN 2 Padang, I found four main responses among female students. First, some girls feel comfortable with the practice because they have been accustomed to covering the whole body so as not to expose the female aurat. Members of this group have no problem with the Mayor's policy; indeed they support it

\footnotetext{
${ }^{39}$ Haluan 03/21/2005.

40 The daily uniform consists of a long-sleeved white blouse and a long grey skirt, while the scout uniform comprises a long-sleeved light brown blouse and a long darkbrown skirt. Meanwhile, the 'traditional' baju kurung encompasses a green long-sleeved blouse and a long black skirt that is completed with a lining. Each uniform is complemented by a matching headscarf. Friday's uniform is baju kurung, Saturday's is the scout outfit, while for all the other days the daily uniform is worn.
} 
because it enforces a religious obligation. Afifah (16) has worn the headscarf since junior high-school, and said that she is happy with the imposition of Islamic attire at her school. Although in this case it was implemented by force, she feels that requiring Muslims to visibly express their religious identity has a positive impact, particularly on teenage girls who should cover their aurat. As is commonly claimed by defenders of the headscarf, Afifah believes that Islamic veiling not only protects her skin from the burning sun, but also from sexual harassment by trouble-making men. Afifah argues that even though covering the body is only compulsory during school hours, it still has a good effect in terms of religious practice. As flaunting the aurat is sinful and covering it is rewarding, she maintains that those who wear the veil at school still get some benefit from the daily practice even if they remove it after school. Even some observance, she says, is better than passing the whole day in sinful behaviour.

Second, there are some who objected to the imposition of veiling at first but then have since become accustomed to wearing Islamic attire. Most of the members of this group have chosen to wear Islamic attire for activities outside school since their school formalised Islamic dress during school hours. Although these girls were initially forced to choose Islamic attire, some of them stated that they are now ikblas ('sincerely accepting') about wearing the veil either in or out of school, for example during private lessons, sightseeing trips and social gatherings. Nurul (19) reveals an ambiguous attitude: she essentially disagrees with the formalisation of Islamic attire because she believes that veiling should not be adopted under compulsion. On the other hand, she admitted that, although she initially felt uncomfortable with wearing the veil, she became used to it after several months. Moreover, she only became aware of the obligation to cover up after her teachers and friends explained the reasoning behind veiling. For these reasons, she has made up her mind to keep wearing the veil, not only at school but also for other activities outside her home. Nurul argues that she has gained a lot of advantages from changing her style of dress. For example, she is no longer bitten by mosquitoes since her body is covered by Islamic attire. Although the percentage of girls at her school who wear full-time Islamic attire is only $30 \%$, Nurul has made the commitment to remain veiled.

Third, quite a number of students disagreed with wearing the veil but felt unwilling to reject the imposition openly. They wear Islamic 
attire in class, but remove it as soon as they step outside the school. They treat their Islamic attire as a school uniform that is worn only for formal education and religious activities, ignoring its religious significance. Members of this group also reveal an ambiguous attitude: they know that wearing the veil is a religious obligation, but they do not yet feel ready to do it. Olvini (17) argues that before a person decides to wear the jilbab, she should be both physically and mentally ready. She feels that she is not yet ready to do the religious costume because for her it is impractical (ribet). She not only unveils for outdoor activities, but also dyes her hair bright colours as a fashion statement. She remarked that her school teachers do not know that she dyes her hair because she wears the veil in class. If there were a choice, she would reject the obligation to wear Islamic attire in school, because it restricts her freedom of expression. For these reasons, she wonders why the Padang Administration decided to impose Islamic attire; other regions that have a Muslim majority among their citizens have not enacted similar policies.

Fourth, several students objected to wearing Islamic attire because they are not Muslim; despite this, they have 'adjusted' their costume to fit in with other students. ${ }^{41}$ Although the Mayor's policy allows nonMuslim students not to wear the headscarf, these students cannot rely fully on this exemption. Social pressure at school forces them to wear Islamic attire. A Catholic student, Nastika (16), admits that it is inconvenient for her to be different from other students in terms of her clothing; furthermore non-Muslim students are in a minority at the school. Therefore, she and other Christian students have decided to wear Islamic attire. Nastika said that it is no use challenging the regulation, although she has profound objections to it. Instead of solving the problem, mounting a challenge would only get her into trouble. Nastika realises that wearing the veil requires commitment and determination, even on the part of those who wish to wear it because they are Muslim; adopting the practice is even harder for non-Muslims. Therefore, compulsory veiling should be unwelcome to everybody.

Given the views expressed above by students at Padang schools, Islamic veiling seems to have been narrowed to 'an imposed choice'

\footnotetext{
41 At the junior high-school level, wearing Islamic attire is required of non-Muslim students at SMPN 20 Padang. According to one teacher, the students do not object to wearing the religious costume, even though they are not Muslims.
} 
rather than a 'personal choice' made as the result of a new 'awareness' (kesadaran) as described by Brenner. ${ }^{42}$ Nurul's experience shows that her will to wear the veil was triggered by the uniform regulations rather than by her own decision. This was in contrast to Afifah who already practiced veiling before the regulation came into force. Although both girls now wear the full-time Islamic veil, Nurul remains somewhat ambiguous about the practice, while the latter feels more certain. Nevertheless, Nurul's attitude is less ambiguous than Olvini's: Olvini feels uncomfortable with wearing the all-enveloping costume, putting it on under compulsion. Consequently, Olvini equates Islamic attire with a school uniform, and discards it as soon as she leaves the school grounds. As more students seem to share this view than either Nurul's or Afifah's, the formalisation of veiling may not lead to a long-term change in women's acceptance of Islamic attire. The reactions of Nurul and Olvini to the 'imposed choice' show how norms and ideas are continuously negotiated in social spaces.

In addition, Islamic veiling has become an oppressive tool used by Muslims against non-Muslim students as a minority group. Nastika's experience shows how she became powerless vis-à-vis the powerful pressure of bureaucratic agents. For example, when she walked along a corridor at her school, a teacher reminded her to wear the veil as other students did. At that time, she just put the headscarf on her shoulders without tightening it around her head. Nastika told the teacher that she is not a Muslim. Nevertheless the teacher kept insisting that she wear the headscarf by demonstrating how to put it on correctly. The teacher told her that although she is not a Muslim, she would do better to 'adjust' to the practices and dress styles of the other students. "This is so [you can] look neat", the teacher added. This teacher also pointed out that "Catholic nuns wear the veil too, don't they?" Such examples of the application of personal pressure show how power works as "the capacity of social agent(s) to impose his/their desire against the defiance of others". ${ }^{43}$ Another example is provided by a statement made by the Padang Mayor on a TV program dealing with Islamic attire. On this talk-show, Nastika witnessed how the Mayor

\footnotetext{
42 S. Brenner, "Reconstructing self and society: Javanese Muslim women and the veil," American Ethnologist, 23, (1996), pp. 673-697.

${ }^{43}$ M. Weber, G. Roth, \& C. Wittich, Economy and Society: an Outline of Interpretive Sociology (Berkeley: University of California Press, 1978), p. 926.
} 
'encouraged' people in Padang to wear Islamic attire by saying, "It is not nice to see a black sheep in a mob of white sheep". This clearly indicated to Nastika that political pressure was being exerted by the Mayor, who wants to standardise the way people dress by repudiating diversity and rejecting individual differences in personal appearance.

\section{Islamic Attire as a Contested Discourse}

Following the widespread institutionalisation of Islamic precepts throughout West Sumatra by means of regional regulations (Perda), the Mayor's policy enforcing Islamic attire in Padang has been welcomed by elements in local society. The efficacy of the policy represents an alliance between a 'ruling political apparatus' and Islamic-based groups that have long campaigned to impose Islamic attire in the public domain. The Mayor's policy amounts to a bureaucratic endorsement of these Islam-oriented groups; at the same time, the Mayor needs their support to pave the way for public acceptance of policy platforms. Nevertheless, some powerful groups have questioned the policy and criticised the imposition of Islamic veiling in a plural society. In the following section, I will first outline the main arguments made by the Mayor's supporters; then I will discuss the dissenting views.

An Aisyiah activist, ${ }^{44}$ Maeliana Rusli, pointed out that the Mayor's policy regarding Islamic veiling reflects a political endorsement of an Islamic society. She believes that the regulation is an effective way for local government to accommodate and facilitate the spread and practice of the Islamic teachings followed by Minangkabau people. For her, the Mayor's position is in line with the Hadith (sayings of the Prophet):

Man ra'a Ainkum munkara, fal yughayyir bi yadibi, wa in lam yastati?

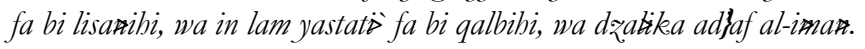

Whoever sees among you an abomination, let him change it with his hand [power], and he who cannot, let him change it with his tongue, and he who cannot, let him change it with his heart, though this be the weakest faith.

\footnotetext{
44 Aisyiah is the organisation for the women's wing of Mubammadiyah. It is the second largest Islamic organisation in Indonesia. According to Rusli, Aisyiab has 14 branches in Padang whose members are about 1400 women. Aisyiah has a special uniform that is usually worn by members during their meetings and other activities. It consists of a sarong, a long-sleeved shirt (baju kurung), and a headscarf.
} 
According to Rusli, the Mayor has a duty to take action, using the power that he has. Given the fact that many girls do not cover their aurat, Rusli argued that this is kemungkaran ('an abomination'): the Mayor should lift his hand (i.e. use his power) to overcome it. Moreover, Rusli speculated that the uncovered bodies of women make them susceptible to sexual harassment. She has found that cases of sexual harassment on buses are mostly triggered by women who flaunt their bodies.

Similar endorsement comes from a Muslim cleric, Buya Masoed Abidin, ${ }^{45}$ who argued that the political decision to impose the veil in schools reflects the expectations of most people in Padang, particularly the Minangkabau, who are the dominant ethnic group. He claimed that $60 \%$ of female Muslims in Padang were already wearing the veil before the local government issued its 'call to action'; furthermore, the majority of Minangkabau women have always worn a traditional headcovering with a sarong and a long-sleeved shirt. Therefore, Abidin believes that what the Mayor has done regarding Islamic veiling reflects common social practice. The Mayor's policy is a good strategy for encouraging the remaining $40 \%$ of Muslim women in Padang to wear the veil, he added. According to Abidin, the Mayor is very clever at meeting people's needs. Because he graduated from teacher-training college and has a family background in teaching, Abidin believes that the Mayor assumed that a standard school uniform would help enforce discipline among students. Since Minangkabau people have traditionally relied on three legal 'pillars' or authorities known as the Tali Tigo Sapilin, Abidin argues that the local government policy represents a significant and legal pillar which has a credible historical basis. ${ }^{46}$

\footnotetext{
45 Buya Masoed Abidin is a member of the board of the Indonesian Ulama Council (MUI) in Padang. He is also an elite member of DDII, Dewan Dakwah Islam Indonesia, or 'The Indonesian Council for the Propagation of Islam'.

46 These three legal pillars are: adat istiadat ('local custom'), undang-undang Negara/pemerintah (the acts and laws of the national and/or regional governments) and religious principles. This concept underpins the social philosophy of traditional Minangkabau society. See H. Sihombing, "Hukum Adat Minangkabau Mengenai Tungku Tiga Sejarangan dan Tali Tiga Sepilin,” in A. A. Navis (ed.), Dialektika Minangkabau (Padang: Genta Singgalang Press, 1983), p. 48.
} 
Rather than presenting religious arguments for the Mayor's policy, Shafwan Karim ${ }^{47}$ defended it because it amounted to an effort to enforce noble conduct (al-akblapal-karimah) and etiquette in terms of clothing standards. Karim is pleased about the Mayor's concern for religious activities in Padang: he gives him credit for promoting religious fora (pengajian), Islamic short-courses (pesantren kilat) and special Ramadłactivities. Karim regards the policy on school uniform as no more than a natural decision to make in Muslim-dominant Padang; he does not consider it to be an extraordinary case of Islamic law enforcement. As he is concerned about moral degradation, Karim regards formalising Islamic veiling as a necessary measure to take in order to overcome the 'social ills' (penyakit masyarakat) alleged to be rampant in Padang. ${ }^{48}$ According to Karim, wearing Islamic attire is not a burden, because it is merely a uniform. Making male students wear baju koko-a long-sleeved collarless plain-coloured shirt that is usually worn to go to prayers ${ }^{49}$-is like obliging factory-workers to wear a uniform. In his opinion, the issue has nothing to do with Islamic teachings. Finally, he pointed out that wearing body-covering attire protects both male and female students from mosquito bites.

Hasna Wirda ${ }^{50}$ also welcomes the Mayor's policy because it is in accord with the aspiration to return to the Minangkabau philosophy: adat basandi syara, syara basandi kitabullah ("Local custom draws on shara', shara' draws on the Qur'a '). In addition, Wirda explained that this philosophy is in accordance with the Minangkabau character: Minangkabau are 'faithful' (beriman-bertakwa) and 'possess a special culture' (berkebudayaan khas). For this reason, she argues, wearing the Islamic veil will come to characterise the Minangkabau people, because 'Minang culture'51 is 'Islamic culture'. In this respect, Wirda speculates

\footnotetext{
${ }^{47}$ Shafwan Karim is the Muhammadiyah Chairperson in Padang. He is also a Rector of Bung Hatta University. After he chose to teach at the university, he gave up his political involvement with the Golkar Party.

48 The penyakit masyarakat or 'social ills' refer to various activities such as gambling, prostitution, theft, etc.

49 The baju koko is a long-sleeved shirt without collar. It is made in a plain colour although this may be bright. Men usually wear it to the mosque, and for prayer.

${ }^{50}$ Hasna Wirda is a former Aisyiyah activist. She is now a lecturer at IAIN Imam Bonjol, Padang.

51 The word Minangkabau is often shortened to Minang. Minangkabau people are commonly referred to as orang Minang.
} 
that the essence of people's aspirations is to return to the Minang identity (jati dir). Wirda laments that due to globalisation, the tradition of wearing modest Islamic clothing had been abandoned by many people. Therefore, she is happy with the current re-education of students to wear Islamic attire at their schools. Accustomed to wearing the headscarf from adolescence, Wirda supports the style of Islamic veiling practiced by female students (Diniyah Putri) in Padang Panjang; this style is called mudarrarab. ${ }^{22}$ This is a special style of headscarf worn at Rahmah El-Yunisiah, an educational institution for women..$^{53}$

In addition to religious figures, Paljariati Yusral, an activist in the Islamic Party (PKS), ${ }^{54}$ supported the formalisation of Islamic attire. Although he admitted that his political affiliation differs from that of the Mayor, he conceded that the policy does indeed support Minangkabau aspirations. Like Hasnawirda, Yusral claimed that enforcing veiling promotes the modern realisation of the identity (jati diri) of the Minangkabau people as it was formulated by their ancestors: adat basandi syara, syara basandi kitabullah. Yusral regards imposing religious standards to be inevitable: it is a necessary practice intended to re-educate people about the importance of living by Islamic precepts. Yusral argues that without any enforcement from leaders, Islamic teachings are often forgotten or ignored, because that is the character of human beings. Yusral lamented that the Mayor's decree was not legally binding, however, because it is instruksi, not Perda-"an instruction, not a law." As a Member of the House of Representatives, Yusral would welcome any proposal for bill requiring

\footnotetext{
52 According to Fauziah Fauzan, a fourth-generation Manager at Diniyah Putri, the mudawarah is a style of headscarf which was modified from the original Arabic style into a style that suited Minang women. It can be tightened neatly.

53 This institution focuses on instruction for women, and is based on the boardingschool system. Its curriculum not only deals with pedagogic and Islamic subjects; it also addresses gender equality and women's issues. According to its motto: "preparing woman to educate the next generation", this institution teaches traditional skills such as cooking, sewing, weaving and technology-based skills. The unique veil students wear was first worn by Rahmah El-Yunisiah, the founder of this institution. She stated that this veil is designed to be worn with baju kurung and a batik sarong, a costume which covers the whole body except the face and hands. She claimed that this model accords with the criteria of Islam teachings. See Anon., Peringatan 55 Tabun Diniyah Putri Padang Panjang (Jakarta: Ghalia Indonesia, n.d.), p, 246).

${ }^{54}$ Paljariati Yusral is Secretary of the Partai Keadilan Sejabtera (PKS, Prosperous Justice Party'), in Padang.
} 
Islamic attire if it is proposed by the Executive. Thus, he exemplifies the aspirations of some members of the House of Representatives particularly those from Islamic parties - to institutionalise Islamic attire in Regional By-law (Perda) passed by the Legislature.

The support of Muslim leaders for the Mayor's policy reflects the Minang people's strong endorsement of enforcing Islamic attire. Rather than being influenced by the ruling apparatus, Islamic figures are personally motivated to institutionalise Islamic attire in public. The impetus for their argument arises not only from their belief that veiling is part of local community tradition; 55 it is also impelled by their monolithic understanding of religious doctrine. ${ }^{56}$ In this respect, their endorsement does not reflect Gramsci's concept of consent as resulting from "the effort of the leading class to entice other social groups to agree to its perspective of the natural". ${ }^{57}$ On the contrary, in this instance the 'consent' stems from the strong impulse of the Muslim population of West Sumatra as predicted by Dobbin, who wrote that Islam is the potential means for Minangkabau people "to reach their goal to control their own destiny". 58

On the other hand, since the imposition of Islamic attire in Padang has no strong basis in terms of the Indonesian hierarchy of binding laws, ${ }^{59}$ dissenting groups question the validity of the Mayor's policy. Miko Kamal, a former $\mathrm{LBH}^{60}$ activist, argues that the 'call to action' is a one-sided policy that involves only the Executive and ignores the existence of the Legislature, the Regional House of Representatives (DPRD); it also contravenes several regulations with higher legal

\footnotetext{
55 Veiling is part of the traditions of Aisyiah, Muhammadiyah and the DDII.

56 The common inclination of Muslims in Padang is to reject liberal thinking in relation to religious doctrine. Several Muslim leaders have insisted on following and enforcing the MUI edict which forbade liberalism, pluralism and secularism (Media Indonesia, 20 Agustus 2005). Further, public choices of which books to read show that the general population of Padang prefers normative to discursive books. Popular choices are fiqh ibadah and classical texts (kitab kuning).

${ }^{57}$ A. Gramsci, History, Philosophy, and Culture in the Young Gramsci (St. Louis: Telos Press, 1975), p. 80.

${ }^{58}$ C. E. Dobbin, Islamic Revivalism in a Changing Peasant Economy: Central Sumatra, 17841847 (London: Curzon Press, 1983), p. 244.

59 See Footnote 3 above, which summarises the five kinds of laws that are recognised as legally binding.

${ }^{60} \mathrm{LBH}$ stands for Lembaga Bantuan Hukum (the Legal Aid Institute).
} 
status, including Law No. 10/2004. Therefore, the policy is basically ad boc. Kamal speculates that the Mayor tends to produce policies as the need arises. In the absence of military force, Kamal contends that the policy merely represents a bureaucratic regulation which conceals a political interest. ${ }^{61}$ If the Mayor is serious about regulating Islamic attire, Kamal argues, he needs to propose a bill concerning it to the Regional House of Representatives.

Sudarto, an NGO activist, ${ }^{62}$ criticises the policy for being an unproductive strategy which is the characteristic of the Padang administration. Sudarto argues that instead of producing a 'call to action', the Mayor should concentrate on crucial social programs, such as education and public welfare. In Sudarto's view, enforcing Islamic veiling in schools will not be effective, because it is being implemented by means of social and political pressure. While veiling is only practiced at school, most female students discard their headscarves outside school hours. Sudarto believes that the policy will be abandoned as soon as the Mayor's term of office ends. Since the policy 'imposes' the Islamic veil on non-Muslim students, Sudarto condemns it as a form of 'moralist-based fascism'. ${ }^{63}$ He speculates that there is almost no resistance to the policy in Padang because it does not capture the public's interest; it does not deal directly with people's main concerns, particularly about the state of the economy. Sudarto contends that it would be different if the policy directly causes some detrimental effects on people economically. In addition to these reasons, he argued that the government intervention in religious practices, particularly regarding the enforcement of Islamic veiling, should not be tolerated. The policy diverts attention from more crucial issues that should be prioritised in local government programs into a comforting political gimmick. ${ }^{64}$ As noted above, however, the compulsory uniform change has caused hardships for many students.

\footnotetext{
61 Although Fauzi Bahar was not a cadre of any political party at the time, in early June 2006 he was elected to become Chairperson of the National Mandate Party (PAN) of Kota Padang. He put himself forward as a candidate at the party's Third Regional Congress, and won 102 votes out of a total of 191. The other contenders, Irdamsyah Nazar and Ahmad Amin, won 45 and 40 votes respectively. See Haluan, 06/12/2006.

62 Sudarto is Director of the Center for Inter-Community Studies (Pusaka).

${ }^{63}$ Indopos, 06/05/2005: 4; http://www.islib.com.

${ }^{64}$ Indopos, 27/05/2005; http://www.islib.com
} 
Lusi Herlina, another NGO activist, questions the relationship between enforcing Islamic veiling and moral improvement. She suggests that wearing Islamic dress will not automatically improve female morality: this is because moral values are not built in a short term period; they are developed gradually over the long term. Herlina also rejects the argument that enforcing Islamic veiling can solve rampant 'social ills' (penyakit masyarakat), because particular social problems have particular solutions. Instead of improving student morality, Herlina speculates that enforcing Islamic veiling will lead to intolerance among them, because they will become unaccustomed to differences, particularly in personal appearance. Since the Mayor's policy targets elementary school students, Herlina is concerned that these children will grow up unfamiliar with diversity; this is not a good thing, because diversity (kebbinnekaan) is very important for children who are still seeking their identities during their formative years.

Amidst the general discussion about the pros and cons of Islamic veiling, the imposition of veiling on non-Muslim students has drawn particular criticism, which has been rejected by the relevant agencies in Padang. In a dialogue held in 2005 between President Susilo Bambang Yudhoyono and elite bureaucrats throughout West Sumatra, the Padang Mayor denied that his policy compels non-Muslim students to wear the Islamic veil. According to the Mayor, the policy works at the level of a 'call to action' (bimbauan) encouraging elementary and secondary school students to wear the Minang costume of a baju kurung and a headscarf. The Mayor stressed that the imposition of Islamic attire was merely intended for Muslims, however. ${ }^{65}$ Similarly, in response to a Jakarta-based magazine's report that a public school in Padang had imposed Islamic veiling on non-Muslim students, ${ }^{66}$ the Principal of the school denied that the school management had ever forced non-Muslim students to wear the Islamic veil. According to the Principal, he had only encouraged non-Muslim students to 'adjust' their clothing in accordance with the Mayor's policy. ${ }^{67}$

Instead of justifying and accommodating Muslim aspirations, the Mayor's policy has been widely regarded as a populist political move, made to rally support for his election to a further term of office.

\footnotetext{
${ }^{65}$ Media Indonesia, 08/26/2005.

66 Tempo, 05/22/2005.

${ }^{67}$ Padang Ekspress, 05/21/2005.
} 
Kamal stated that if one looks at the Mayor's actions in relation to Islamic-based issues, one can see that the Mayor wants to make a good impression on Islamic voters. According to Kamal, the Mayor's decision to impose Islamic attire cannot be separated from his intention to gain the sympathy of the Muslim majority, despite the fact that he is not himself a devout Muslim. In addition, Kamal contended that the election of the Mayor as Chairperson of the National Mandate Party (PAN) in Kota Padang during his tenure as Mayor clearly indicated his ambition to gather support from political parties before the next Mayoral election. According to Kamal, once the Mayor has control of one significant political party, he will expand his power to gain control of others. Paljariati Yusral rejects such a cynical assumption, however, and encourages people to freely judge the Mayor's motives. Yusral regards the Mayor's policy as an aspect of a strategic effort to make Padang a religious society. Yusral argues that everyone has the right to participate in the next direct election (Pilkada) for the position of Mayor, and people can assess the success of his performance in office.

\section{Conclusion}

The experience of Minangkabau people in Padang in negotiating their conflicting ideas regarding veiling reflects the unproductive outcome of promoting Islamic attire in a complex Muslim society which is not structured along traditional Arab lines. The regulation requiring Islamic attire in Padang has constitutional problems; thus it is profoundly ambivalent in terms of both its implementation and the arguments used to explain and defend it. Moreover, the regulation has been implemented in line with the growing trend towards Islamic attire in Muslim regions in Indonesia. Instead of encouraging religious awareness, however, the imposition of veiling has made the veil into a purely formal obligation: it has lost its profound inner meaning for those who wear it. According to Padang students, veiling is part of a school uniform ${ }^{68}$ that must be worn in the school grounds. To some extent, the imposition of Islamic dress has made the veil into a tool of oppression - particularly for non-Muslim students who were forced to adopt this symbol of Islamic identity - rather than a liberating personal choice.

${ }^{68}$ Parker found a similar situation in Bukittinggi, Inside Indonesia (July-September, 2005). 
The enforcement of Islamic veiling in Padang rests on a flawed religious conceptualisation. Consequently, the justification for the imposition of Islamic veiling leads to a 'fallacy' rather than encouraging a logical way of thinking. The attempts made by certain religious figures to indoctrinate the population with the idea of veiling as an obligation has culminated in a monolithic interpretation, whereas Islamic jurisprudence (fiqh) and Qur'anic exegesis (tafsip provide various complex interpretations about veiling and the female body. Due to this complexity, efforts to impose compulsory Islamic veiling are as difficult as convincing everyone to have a single taste and style in how they dress. In addition, the rationale for veiling as a preventative measure against sexual harassment, the sun, and mosquito bites is a superficial attempt to hide the lack of serious government effort to address the roots of social problems and law enforcement on the one hand, and the management of community health to eradicate diseasecarrying mosquitoes on the other.

From the time that the regulation on Islamic veiling was imposed on the subaltern, the characteristics of orthodoxy have been reflected in both social interactions and discourse. Orthodoxy is characterised by the following features as Berlinerblau has identified; collaboration among social groups; control of the means of material, intellectual and symbolic production; constructing correct and incorrect forms of belief and praxis; and the engagement of coercive mechanisms. ${ }^{69}$ In enacting regulations about acceptable dress, the local government bureaucracy and religious groups have collaborated to formalise Islamic attire on the grounds of their common interest. While the Mayor as formal leader needs only a superficial and popular program, other groups require political support from their constituents. In order to realise the goal of following Islam, the headscarf and baju kurung have been stipulated to be the correct and representative Islamic attire for women. Both government and religious figures have promoted the advantages of Islamic veiling as a 'panacea' for sexual harassment, criminal conduct and mosquito bites to justify their support for regulations that impose Islamic veiling in public. Meanwhile, groups which support this policy define correct and incorrect forms of women's attire in accordance with Islamic criteria for proper dress,

${ }^{69}$ J. Berlinerblau, "Toward a Sociology of Heresy, Orthodoxy and Doxa," History of Religions, 40, (2001), pp. 327-351; p. 340. 
such as: long and loose clothing that covers the hair, neck and chest, and is made of opaque materials and not body-hugging. With such criteria institutionalised in the regulations, enforcement inevitably creates coercion by means of imposing sanctions.

All discussion above led to conclusion of the failure of Islamists in the formalization approach which created a "peculiar regulations" for their arbitrary paradigm of which aspects of religiosity are deserved to be regulated and which parts of religious aspects should be left as a personal choice. The imposition of Islamic attire does not only tend to put female Muslims as a victim of religious regime and political interests, but also contravene the nature of Islam which inherently dignifies freedom of religious expressions. As a new episode of Indonesian Islam, the emergence of Sharith-related by-laws has trapped Muslims into emphasizing the need of symbolic aspects of religiosity without prioritizing its substantive aspects. This current trend certainly becomes a challenging reality for the future of local Islam which profoundly determines the whole picture of Indonesian Islam. []

\section{Bibliography}

\section{Books and Articles}

Abdullah, T., Summerfield, A., Summerfield, J. \& University of California Los Angeles. "Fowler Museum of Cultural History." in Walk in Splendor: Ceremonial Dress and the Minangkabau. Los Angeles: UCLA Fowler Museum of Cultural History, 1999.

Abdullah, T. Identity Maintenance and Crisis of Identity in Minangkabau. Jakarta: Lembaga Ekonomi dan Kemasyarakatan Nasional, 1978.

--------. Sejarah Lokal di Indonesia: Kumpulan Tulisan. Yogyakarta: Gadjah Mada University Press, 1985.

Abu-Lughod, L. "The Romance of Resistance: Tracing Transformation of Power Through Bedoin Women." American Ethnologist, 17 (1990): pp. 41-55.

Alatas, A. \& Desliyanti, F. Revolusi Jilbab: Kasus Pelarangan Jilbab di SMA Negeri se-Jabotabek, 1982-1991. Jakarta: Al-I'tishom Cahaya Umat, 2001. 
Anon., Peringatan 55 Tabun Diniyah Putri Padang Panjang. Jakarta: Ghalia Indonesia, n.d.

Berlinerblau, J. "Toward a Sociology of Heresy, Orthodoxy and Doxa." History of Religions, 40 (2001): pp. 327-351.

Bensman, J. \&. Givant, M. "Charisma and Modernity: The use and abuse of a concept." in Glassman, R. M. \& Swatos, WH. Jr (Eds.). Charisma, History and Social Structure. New York: Greenwood Press, 1986.

Boland, B. J. The Struggle of Islam in Modern Indonesia. Leiden: The Hague-Martinus Nijhoff, 1971.

Bowen, J. R. Islam, Law, and Equality in Indonesia: an Anthropology of Public Reasoning. Cambridge, UK: New York, Cambridge University Press, 2003.

Brenner, S. "Reconstructing self and society: Javanese Muslim women and the veil." American Ethnologist, 23 (1996): pp. 673-697.

Dobbin, C. E. Islamic Revivalism in a Changing Peasant Economy: Central Sumatra, 1784-1847. London: Curzon Press, 1983.

Driver, G. R., Miles, S. J. C. \& ASSYRIA. The Assyrian laws.

El Guindi, F. Veil: Modesty, Privacy and Resistance. Oxford, UK: New York, NY, Berg., 1999.

Feillard, A. "The Veil and Polygamy: Current Debates on Women and Islam in Indonesia.” Moussons, 99 (1999): pp. 5-28.

Foucault, M. The History of sexuality. New York: Pantheon Books, 1978.

Gramsci, A. History, Philosophy and Culture in the Young Gramsci. St.Louis: Telos Press, 1975.

Haba, J., Mulyani, L. \& Pusat Penelitian dan Pengembangan Kemasyarakatan dan Kebudayaan (Indonesia). Nagari dan Krama Desa: Studi mengenai Pemiliban Struktur antara Perilaku Elit dan Masyarakat Lokal di Sumatra Barat dan Nusa Tenggara Barat. Jakarta: Pusat Penelitian Kemasyarakatan dan Kebudayaan Lembaga Ilmu Pengetahuan Indonesia (PMB-LIPI), 2001.

Kuntowijoyo. Muslim tanpa Masjid: Esai-esai Agama, Budaya, dan Politik dalam Bingkai Strukturalisme Transendental. Bandung: Mizan, 2001.

Marbun, S. F. \& MD, Mahfud. Pokok-pokok Hukum Administrasi Negara. Yogyakarta: Liberty, 1987. 
Munir, D. \& Padang (Indonesia) Dinas Infokom. 1 tahun Walikota \& Wakil Walikota Padang: Drs. H. Fauri Bahar, M.Si \& Drs. H. Yusman Kasim: 18 Februari 2004-17 Februari 2005. Padang: Dinas Infokom Kota Padang, 2005.

Parker, L. “Uniform Jilbab.” Inside Indonesia. July-September 2005.

Safwan, M. \& Proyek Inventarisasi dan Dokumentasi Sejarah Nasional (Indonesia). Sejarah Kota Padang. Jakarta: Departemen Pendidikan dan Kebudayaan, Direktorat Sejarah dan Nilai Tradisional, Proyek Inventarisasi dan Dokumentasi Sejarah Nasional, 1987.

Sihombing, H. "Hukum Adat Minangkabau Mengenai Tungku Tiga Sejarangan dan Tali Tiga Sepilin." in A. A. Navis (ed.). Dialektika Minangkabau. Padang: Genta Singgalang Press, 1983.

Weber, M., Roth, G. \& Wittich, C. Economy and Society: an Outline of Interpretive Sociology. Berkeley: University of California Press, 1978.

Whalley, L. A. "Virtuous Women, Productive Citizens: Negotiating Tradition, Islam, and Modernity in Minangkabau, Indonesia." Unpublished $\mathrm{PhD}$ thesis, University of Illinois, UrbanaChampaign, 1993.

\section{Newspapers}

Haluan, 11 February 2005.

Haluan, 12 June 2006

Haluan, 21 March 2005.

Indopos, 05 June 2005.

Indopos, 27 May 2005.

Media Indonesia, 26 August 2005.

Padang Ekespress, 21 May 2005.

Tempo, 22 May 2005. 